\title{
DAYA ANTIBAKTERI EKSTRAK ETANOL DAUN SENGGANI (Melastoma affine D. Don)
}

\author{
Ika Trisharyanti Dian Kusumowati ${ }^{1}$, Rosita Melannisa ${ }^{1}$, Angga Prasetyawan ${ }^{1}$ \\ ${ }^{1}$ Fakultas Farmasi Universitas Muhammadiyah Surakarta \\ Correspondence to : Ika Trisharyanti Dian Kusumowati \\ email: Ika.Trisharyanti@ums.ac.id
}

\begin{abstract}
Melastoma affine D. Don had some activities such as anthelmintic, antibacteria, antiinflammation, antifungal, and antitumor. The aims of this research was determine antibacteria activity of ethanolic extract of Melastoma affine D. Don. The antimicrobial activity was tested by solid dilution method to get Minimum Inhibition Concentration (MIC). The compounds in Melastoma affine D. Don was analyzed by tube test method and Thin Layer Chromatography (TLC) with chloroform : methanol: formic acid (8,5:1,5:0,5) as mobile phase and silica gel GF254 as stationary phase. The result showed ethanolic extract of Melastoma affine D. Don contains alkaloid, polyphenol, flavonoid, saponin, and essential oil. The MIC of Senggani against Staphylococcus aureus was 2\% and 3\% against Escherichia coli and the extract could not inhibit Staphylococcus aureus and Escherichia coli multiresistant until concentration $7 \%$ extract ethanol.
\end{abstract}

Keywords: Melastoma affine D. Don, Staphylococcus aureus, Escherichia coli

\section{PENDAHULUAN}

Penyakit infeksi merupakan ancaman bagi kelangsungan hidup manusia. Beberapa bakteri yang dapat menyebabkan penyakit diantaranya adalah Staphylococcus aureus (S. aureus) dan Escherichia coli (E. coli) (Jawetz et al., 2005). Hampir setiap orang pernah mengalami berbagai infeksi $S$. aureus selama hidupnya, dari keracunan makanan yang berat atau infeksi lesi kulit yang kecil. Infeksi $S$. aureus juga dapat berasal dari kontaminasi langsung dari luka dan jika infeksi ini menyebar dan terjadi bakterimia, maka bisa terjadi endokartitis, meningitis dan infeksi terhadap paruparu (Jawetz et al., 2005). E. coli merupakan penyebab paling banyak dari infeksi saluran kencing dan juga menyebabkan diare, sepsis, dan meningitis (Jawetz et al., 2005).

Penanggulangan penyakit infeksi umumnya dilakukan dengan pemberian antibiotik. Penggunaan antibiotik yang tidak tepat, seperti kurang tepatnya indikasi penggunaan, penggunaan bebas oleh masyarakat, serta dosis dan lama pemberian yang tidak tepat, akan menimbulkan masalah baru yaitu meningkatnya resistensi bakteri terhadap antibiotik. Untuk mengatasi masalah tersebut, diperlukan upaya pengembangan antibiotik baru, salah satunya dengan memanfaatkan tumbuhan obat yang ada di sekitar kita.

Tanaman berkhasiat obat, yang dikenal masyarakat adalah Senggani (Melastoma affine D. Don) dari suku Melastomaceae. Tanaman ini berkhasiat sebagai penurun demam (antipiretik), pereda nyeri (analgesik), peluruh air seni (diuretik), mengobati keputihan (leukorea), dan dapat mengobati berbagai jenis luka tersayat (Dalimartha, 2000). Hasil skrining fitokimia menunjukkan bahwa ekstrak metanol daun Senggani mengandung senyawa tanin, flavonoid, steroid, saponin, dan kuinon. Fraksi etil asetat ekstrak metanol daun Senggani mempunyai aktivitas antibakteri terhadap bakteri S. aureus, E. coli, dan Bacilus cereus dengan KHM (Kadar Hambat Minimal) untuk S. aureus 0,78-1,56\%, untuk E. coli $25-50 \%$, dan Bacilus cereus 0,39$0,78 \%$ dengan metode difusi agar (Titi et al., 2007). 
Berdasarkan uraian tersebut maka penelitian ini dimaksudkan untuk menguji aktivitas antibakteri ekstrak etanol daun Senggani terhadap bakteri S. aureus, E. coli, S. aureus multiresisten (MR), dan E. coli multiresisten (MR) sehingga dapat dijadikan sebagai acuan pengobatan herbal untuk pengobatan penyakit yang disebabkan oleh bakteri.

\section{METODE}

\section{Bahan dan Alat}

\section{a. Bahan}

Ekstrak etanol 96\% daun Senggani dari Fakultas Farmasi UMS, bakteri $S$. aureus, E. coli, S. aureus MR, E. coli MR yang diperoleh dari Laboratorium Biologi Fakultas Farmasi UMS, akuades steril, media BHI (Brain Heart Infusion) (Oxoid), media MH (Mueller Hinton) (Oxoid), media SDA (Sabouroud Dextrose Agar) (Oxoid), cat Gram A, B, C, dan D, CMC Na $0,5 \%$ (Merck), dan alkohol 70\%, silika gel $\mathrm{GF}_{254}$, etil asetat p.a (Merck), asam asetat glasial p.a (Merck), akuades, asam formiat p.a (Merck) dan pereaksi semprot anisaldehid- $\mathrm{H}_{2} \mathrm{SO}_{4}$, Liebermann-Burchard, $\mathrm{KOH}$ etanolik, $\mathrm{FeCl}_{3}$, Dragendorff, dan sitroborat.

\section{b. Alat}

Alat timbang (Ohaus), alat-alat gelas, bunsen, autoclave (Pressure steam sterilizer electric model N0. 25X), Laminar Air Flow (LAF) (CV. Srikandi), oven (Memmert), vortek (Thermolyne Corporation), inkubator bakteri (Memmert), mikroskop (Olympus).

\section{Cara Kerja}

\section{a. Pembuatan ekstrak}

Ekstrak etanol daun Senggani yang digunakan dalam penelitian ini diperoleh dari Fakultas Farmasi Universitas Muhammadiyah Surakarta. Proses pembuatan ekstrak sebagai berikut: Ekstrak dibuat dengan cara maserasi dengan menggunakan etanol 96\%. Satu bagian serbuk kering daun Senggani dimasukkan ke dalam maserator, ditambah 10 bagian etanol 96\%, direndam selama 6 jam sambil sekali-kali diaduk, kemudian didiamkan sampai 24 jam. Maserat dipisahkan dan proses diulangi 2 kali dengan jenis dan jumlah pelarut yang sama. Semua maserat dikumpulkan dan diuapkan dengan penguap vakum hingga diperoleh ekstrak kental.

\section{b. Uji Aktivitas Antibakteri}

Seri konsentrasi ekstrak etanol yang telah dibuat, masing-masing ditambah dengan media $\mathrm{MH}$, dikocok hingga benarbenar homogen, kemudian dipadatkan dalam posisi miring. Selanjutnya jika media yang telah dicampur ekstrak telah padat, sebanyak $50 \mu \mathrm{L}$ suspensi bakteri yang telah dibuat setara dengan $1 \times 10^{6} \mathrm{CFU} /$ $\mathrm{mL}$ diteteskan ke dalam media, kemudian diratakan dengan ose steril, selanjutnya diinkubasi pada suhu $37^{\circ} \mathrm{C}$ selama 18 24 jam. Kemudian diamati pertumbuhan mikrobanya. Kadar terkecil yang dapat membunuh mikroba disebut Kadar Hambat Minimal (KHM).

\section{c. Uji Kualitatif Ekstrak}

\section{Uji alkaloid}

Ekstrak etanol dimasukkan dalam tabung reaksi ditambah $1 \mathrm{~mL} \mathrm{HCl} 2 \mathrm{~N}$, dipanaskan di atas tangas air selama 2 menit, didinginkan dan disaring. Filtrat diambil 3 tetes dan diletakkan pada kaca arloji, kemudian ditambah 2 tetes larutan Bouchardat. Jika tidak terbentuk endapan, maka tidak mengandung senyawa alkaloid. Filtrat jika direaksikan dengan Mayer LP akan terbentuk endapan yang menggumpal berwarna putih atau kuning yang larut dalam metanol $\mathrm{P}$ dan jika filtrat direaksikan dengan Bouchardat membentuk endapan coklat sampai hitam, ada kemungkinan terdapat alkaloid (Anonim, 1989).

\section{Uji saponin}

Ekstrak etanol dimasukkan dalam tabung reaksi, ditambah $10 \mathrm{~mL}$ air panas dan dikocok kuat selama 10 detik akan terbentuk buih mantap selama tidak kurang dari 10 menit setinggi $1-10 \mathrm{~cm}$. Pada penambahan 1 tetes $\mathrm{HCl} 2 \mathrm{~N}$, buih tidak hilang menunjukkan adanya senyawa saponin (Anonim, 1989).

\section{Uji polifenol}

Ekstrak etanol dimasukkan dalam tabung reaksi ditambah $10 \mathrm{~mL}$ air dan 
dipanaskan selama 10 menit. Larutan didinginkan, kemudian disaring. Filtrat yang diperoleh ditetesi dengan $\mathrm{FeCl}_{3}$ sebanyak 3 tetes, kemudian diamati perubahan warna larutan. Hasil positif menunjukan adanya senyawa polifenol adalah terbentuknya larutan berwarna ungu sampai biru (Anonim, 1989).

\section{Uji tanin}

Ekstrak etanol dimasukkan dalam tabung reaksi ditambah $10 \mathrm{~mL}$ air dan dipanaskan selama 30 menit. Larutan disaring dan ditambah $1 \mathrm{~mL} \mathrm{NaCl} 2 \%$ maka akan terbentuk suspensi atau endapan lalu disaring. Filtrat ditambah dengan $5 \mathrm{~mL}$ larutan gelatin $1 \%$. Jika terbentuk endapan maka dapat diindikasikan terdapat senyawa tanin (Anonim, 1989).

\section{Uji flavonoid}

Ekstrak etanol disari dengan 10 $\mathrm{mL}$ metanol dengan pendingin balik selama 10 menit, disaring selagi panas. Filtrat diencerkan dengan $10 \mathrm{~mL}$ air lalu didinginkan, setelah dingin ditambah 5 $\mathrm{mL}$ eter, dikocok dengan hati-hati lalu didiamkan. Lapisan metanol (lapisan bawah) diambil dan diuapkan pada suhu $40^{\circ} \mathrm{C}$. Residu dilarutkan dalam $5 \mathrm{~mL}$ etil asetat, disaring. Filtrat diuapkan hingga kering kemudian direaksikan dengan aseton $\mathrm{P}$, sedikit asam borat dan asam oksalat, dipanaskan hati-hati dalam penangas air. Sisa yang diperoleh ditambah $10 \mathrm{~mL}$ eter dan diamati dibawah sinar UV $366 \mathrm{~nm}$, jika larutan berflouresensi kuning intensif, menunjukkan adanya flavonoid (Anonim, 1989).

\section{Uji Kromatografi Lapis Tipis}

Fase diam yang digunakan adalah silika gel GF 254, fase gerak yang digunakan adalah kloroform:methanol:asam format $(8,5: 1,5: 0,5)$.

\section{HASIL DAN PEMBAHASAN}

Uji aktivitas antibakteri bertujuan untuk mengetahui aktivitas ekstrak etanol daun Senggani terhadap bakteri $S$. aureus, E. coli, $S$. aureus MR, dan E. coli MR. Uji ini dilakukan dengan menggunakan metode dilusi padat dan hasil yang diperoleh adalah nilai Kadar Hambat Minimal (KHM), yaitu kadar terkecil ekstrak etanol daun
Senggani yang dapat menghambat pertumbuhan bakteri.

Uji antibakteri menggunakan 3 macam kontrol. Uji terhadap kontrol media menunjukkan bahwa media yang digunakan benar-benar steril, hal ini ditunjukkan dengan tidak adanya pertumbuhan mikroba pada kontrol media. Kontrol pertumbuhan dan kontrol suspending agent menunjukkan bahwa bakteri dapat tumbuh baik, sehingga dapat diketahui bahwa $\mathrm{CMC} \mathrm{Na}$ $0,5 \%$ tidak memiliki aktivitas antibakteri dan masing-masing media yang digunakan merupakan media yang cocok untuk pertumbuhan $S$. aureus dan E. coli.

Uji aktivitas antibakteri ekstrak etanol daun Senggani terhadap $S$. aureus menunjukkan nilai KHM adalah $2 \%$ sedangkan KHM terhadap $E$. coli adalah 3\%. Uji daun Senggani terhadap bakteri Staphylococcus aureus dan Escherichia coli multiresisten, masih menunjukkan pertumbuhan sampai kadar ekstrak 7\%. Nilai KHM untuk $E$. coli adalah 3\%, jauh berbeda dengan penelitian sebelumnya yang mendapatkan nilai KHM 25$50 \%$ (Titi et al., 2007). Perbedaan ini dapat disebabkan asal tanaman, perbedaan metode yang digunakan, dan perbedaan pelarut yang digunakan. Titi et al. (2007) menggunakan pelarut metanol dan fraksi etil asetat. Pelarut metanol bersifat lebih polar daripada etanol, sehingga dapat menyari senyawa-senyawa polar seperti senyawa fenol yang memiliki banyak gugus hidroksi.

Hasil uji aktivitas antibakteri daun Senggani menunjukkan bahwa aktivitas antibakteri ekstrak etanol daun Senggani lebih tinggi terhadap $S$. aureus daripada E. coli. Hal tersebut dapat diakibatkan perbedaan dinding sel mikroba yang merupakan penentu penetrasi, ikatan, dan aktivitas obat (Jawetz et al., 2005). Dinding sel bakteri $S$. aureus berlapis tunggal dan tersusun atas peptidoglikan (protein dan gula) serta lipid dengan kadar rendah (1-4\%), sehingga ekstrak etanol yang mengandung senyawa-senyawa polar seperti flavonoid lebih mudah menembus dinding sel. Dinding sel bakteri E. coli lebih sulit ditembus senyawa yang bersifat polar karena struktur dinding sel bakteri ini berlapis tiga yang tersusun atas peptidoglikan dan lipid dengan kadar yang tinggi (11-22\%). Hasil uji terhadap bakteri multiresisten, sampai kadar ekstrak etanol daun Senggani 7\% belum menunjukkan kematian bakteri. 
Hasil skrining fitokimia ekstrak etanol daun Senggani menunjukkan adanya kandungan polifenol, tannin, saponin, dan flavonoid. Hasil skrining menunjukkan bahwa ekstrak etanol daun Senggani positif mengandung polifenol dengan terbentuknya larutan berwarna hijau sampai biru setelah ditetesi reagen $\mathrm{FeCl}_{3}$ yang disebabkan adanya reaksi komplek antara polifenol dengan $\mathrm{FeCl}_{3}$. Adanya tanin ditunjukkan dengan terbentuknya endapan setelah ditambahkan gelatin $1 \%$. Saponin ditunjukkan dengan terbentuknya buih yang stabil. Flavonoid juga ditunjukkan dengan fluoresensi kuning intensif di bawah sinar UV 366 nm (Wagner dan Bladt, 1996).

Analisis KLT daun Senggani menunjukkan adanya polifenol pada Rf 0,4. Bercak tersebut setelah disemprot dengan $\mathrm{FeCl}_{3}$ dan diamati secara visual, memberikan warna kelabu. Positif flavonoid ditunjukkan pada Rf 0,7. Hasil KLT menunjukkan di bawah sinar $\mathrm{UV}_{254 \mathrm{~nm}}$ terjadi pemadaman becak, pada UV 366 didapatkan bercak fluoresensi kuning kemerahan. Berdasarkan analisis KLT, daun Senggani tidak mengandung alkaloid, minyak atsiri, dan saponin.

Kandungan senyawa flavonoid, polifenol, tannin, dan saponin pada daun Senggani, kemungkinan berkontribusi terhadap aktivitas antibakteri. Aktivitas antibakteri dari saponin diduga melalui sifatnya yang memiliki gugus polar dan non polar seperti sabun yang merupakan senyawa aktif permukaan yang kuat sehingga dapat menurunkan tegangan permukaan dinding sel bakteri (Hertiani et al., 2003 cit Robinson, 1995). Diabsorbsinya saponin pada permukaan sel akan menyebabkan naiknya permeabilitas sehingga membran sel menjadi bocor atau rusak yang dapat menimbulkan kebocoran konstituen sel yang esensial (Jawetz et al., 2005). Senyawa flavonoid dapat mendenaturasi protein sel bakteri sehingga mengubah struktur dan menghilangkan sifatsifat khasnya (Tjay dan Raharja, 2002). Senyawa flavonoid memiliki aktivitas antibakteri karena dapat membentuk senyawa kompleks dengan protein yang terdapat pada dinding sel maupun protoplas sel (Hertiani et al., 2003) dan senyawa polifenol bekerja dengan cara mempresipitasikan protein sel bakteri (Robbers, 1996).

\section{SIMPULAN}

1. Ekstrak etanol daun Senggani mempunyai KHM terhadap $S$. aureus pada konsentrasi 2\%, sedangkan KHM terhadap E. coli sebesar $3 \%$, dan belum mampu membunuh bakteri $S$. aureus MR dan E. coli MR sampai kadar 7\%.

2. Ekstrak etanol daun Senggani mengandung senyawa polifenol, flavonoid, tannin, dan saponin.

\section{DAFTAR PUSTAKA}

Anonim. 1989. Materia Medika Indonesia. Jilid V. Departemen Kesehatan Republik Indonesia. Jakarta. 549-553

Dalimartha, S. 2000. Atlas Tumbuhan Obat Indonesia. Jilid I. Trubus Argo Widya. Jakarta. 68-69.

Hertiani T., Palupi, I.S., Sanliferianti, \& Nurwindasari, H.D. 2003. Uji Potensi Antimikroba terhadap S. aureus, E. coli, Shigella dysentriae, dan Candida albicans dari Beberapa Tanaman Obat Tradisional untuk Penyakit Infeksi. Pharmacon. Vol. 4 No. 2. UMS. Surakarta.

Jawetz, E., Melnick, J.L., \& Adelberg, E.A. 2005. Mikrobiologi Kedokteran. diterjemahkan oleh Mudihardi, E., Kuntaman, Wasito, E.B., Mertaniasih, N.M., Harsono, S., Alimsardjono, L. Edisi XXII. Penerbit Salemba Medika. Jakarta. 327-335. 362363.

Robbers, S.E., Speedie, M.K., Tyler, V.E. 1996. Pharmacognosy and Pharmacobiotechnology. A. Waverly Company. USA. 139-140.

Robinson, T. 1995. Kandungan Organik Tumbuhan Tinggi. Edisi VI. diterjemahkan oleh Padmawinata, K. Institut Pertanian Bandung. Bandung.

Titi, N.W., Rusmiati, D., Farida, Y. 2007. Aktivitas Antibakteri Ekstrak Dan Fraksi Ekstrak Daun Senggani (Melastoma malabathricum Linn.) Terhadap Staphylococcus aureus, Escherichia coli, Dan Bacillus cereus Dengan Metode Difusi Agar. Farmaka. 5 (3).

Tjay dan Raharja. 2002. Obat-obat Penting: Khasiat, penggunaan dan Efek-efek Samping. Departemen Kesehatan Republik Indonesia. Jakarta.

Wagner, H. \& Bladt, S. 1996. Plant Drug Analysis A Thin Layer Chromatography Atlas. Second Edition. Springer German. 